\title{
Geometry and Measurement in Quran
}

\section{Nuril Huda}

Tadris Matematika, UIN Maulana Malik Ibrahim Malang, Indonesia

\begin{tabular}{ll}
\hline Article Info & Abstract \\
\hline $\begin{array}{l}\text { Submitted : 18-05-2020 } \\
\text { Revised :07-08-2020 }\end{array}$ & $\begin{array}{l}\text { The Quran contains the basic principles of science and civilization. These } \\
\text { sciences include natural science and mathematics. The study of mathematics }\end{array}$ \\
Accepted :07-11-2020 & $\begin{array}{l}\text { covers algebra, statistics, logic, geometry, measurement, and others. This } \\
\text { research aimed to examine the verses of the Quran, which contain geometry and } \\
\text { measurement concepts. This research employed the descriptive-qualitative } \\
\text { method with library research design. This research revealed that the Quran } \\
\text { contains five concepts of geometry: three concepts of line and two concepts of }\end{array}$ \\
*Correspondence: & $\begin{array}{l}\text { angle. Meanwhile, the Quran also contains fourteen concepts of measurement: } \\
\text { six units of time, five units of weight, two units of area, and two units of length } \\
\text { or distance. }\end{array}$
\end{tabular}

Keywords: Mathematics; Geometry; Measurement; Quran.

http://ejournal.radenintan.ac.id/index.php/al-jabar/index

\section{Introduction}

Islam pays excellent attention to science, either religious sciences, natural sciences, social sciences, or philosophy. Islam also encourages people to study by exploiting the potential of human reasoning. Science is needed by humans to achieve happiness in this world and the hereafter. Many Muslim scientists have played a significant role in the progress of various fields of science. Some of the Muslim mathematics scientists are Al-Khawarizmi, Al-Biruni, and Salman Al-Farisi. Some other examples are a scientist named, an astronomer named Al-Fazari, an expert in optics named Abu Ali Al-Hasan Ibn al-Haytham, a chemist named Jabir Ibn Hayan, and a physicist named Abu Raihan Muhammad al-Baituni (Nata, 2018). Recently, research and observations are continuously conducted t to develop science and technology.

One of the main contents contained in the Quran is science. In the Quran, the word 'ilm is mentioned 105, and the derivations of ilm are mentioned more than 744 times (Raharjo, 2002). Quran as a civilization does not only mean that the Quran contains specific theories that can be applied in various scientific experiments; instead, it contains the basic principles of science and civilization. The Quran itself contains many science and technology concepts and praise for knowledgeable people (Qutub, 2011). The Quran is worth mentioning as a source that provides motivation and inspiration to give birth to knowledge and civilization.

A problem occurs when there is a dichotomy between religion and general science. The attitude that underestimates the two is unfavorable attitudes. Religious circles consider general science unimportant because general knowledge is built not on religious guidance and even rejects religious teachings. On the other hand, scientists consider that religious science does not have scientific requirements and is not the result of observations and experiments (Nata, 2018). Furthermore, Nata explains another problem: the view that the source of knowledge in the universe is considered independent without having anything to do with God. The dichotomy problem of science affecting each science's perspective becomes limited, denigrating the role, function, and responsibility of science as a trustworthy source. 
Efforts made to overcome the dichotomy of science are to integrate knowledge so that each science can contribute to society intellectually, socially, morally, culturally, and spiritually (Nata, 2018 ). One of the science integration models is the Science Tree Model proposed by Imam Suprayogo (Suprayogo, 2016). The integration of science with the Science Tree Model explains that Arabic, English, logic, and the introduction to natural sciences and social sciences are the strong roots that must be mastered well. The strong trunk of the tree depicts material from the source of the teachings, which consist of the Quran and Hadith. The branches describe several sciences, such as natural sciences, social sciences, and humanities. As a tree, it must grow on fertile soil. The fertile soil illustrates Islamic life's culture, such as faith, noble morals, and spiritual activities. The tree itself depicts an academic building that produces lush and fresh fruit, namely Islamic education, including faith, good deeds, and noble traits (Suprayogo, 2016).

Thabathaba'l (Mas'ud, 2008) says that science covers natural science and mathematics. One of the Quranic verses that motivate to study natural science and mathematics is found in QS Yunus (10) verse 5, which means:

"He is the One Who made the sun a radiant source and the moon a reflected light, with precisely ordained phases, so that you may know the number of years and calculation 'of time. Allah did not create all this except for a purpose. He makes the signs clear for people of knowledge.

From the verse, it appears that Allah motivates humans to learn the science of calculation. The fields of computation inspired by this verse are astronomy and mathematics. Mathematics cannot be separated from everyday life, either directly or indirectly. Mathematics is a science branch that studies how to count and measure things with numbers and symbols (Mas'ud, 2008; Nasution, 2017). Mathematics is the science of patterns and logic and can be a useful tool for modeling various science domains so that it is called the mother of science (Chiu, 2007). Priyanto states that every branch of science has a lot to do with mathematics to make learning science (Priyanto, 2009). Several mathematics uses are calculating profit, calculating savings and salary, calculating the distance to the house, calculating travel time, calculating vehicle speed, and others. Also, mathematics is an essential school subject since it is included in the national curriculum. The subject of mathematics studies includes algebra, statistics, logic, geometry, measurement, and others.

Geometry is a branch of mathematics that is taught at every level of education. It is a part of mathematics that is very close to students because almost all visual objects are geometric objects (Safrina et al., 2014). Geometry can be said to be one of the materials that are considered important in mathematics. According to Usiskin (1982), geometry needs to be taught because it is the only field of mathematics that can relate mathematics to the physical form of the real world. Second, geometry is the only thing that can allow mathematical ideas to be visualized. Third, geometry can provide a non-singular example of a mathematical system. There are many applications of geometry in mathematics, including determining the geometric shape of a computer network topology (Harahap et al., 2016), determining the angle of inclination of stairs, determining the angles of a clock, and transforming shapes.

At school, geometry learning materials cover points, lines, angles, and two and threedimensional shapes. Geometry materials at the elementary school, junior high school, and senior high school are related to the material's increasing breadth and depth. The 2017 revised edition of the curriculum 2013 contains core competencies and essential competencies regarding geometry. At the elementary school level, students recognize the geometric and plane shapes, 
identify their characteristics and properties, explain the angles and the types of angles, explain line segments, and explain the relationships between lines. At the junior high school level, students analyze the relationships between lines and explain geometric transformations with the concept of Cartesian coordinates. Students explain geometric transformations using matrices' concepts at the high school level, analyze circles, and determine distances (between points, points to lines, and points to planes).

According to Van Hiele's theory (Clements \& Batttista, 1992; Crowley, 1987; Nurani et al., 2016; Rouadi \& Husni, 2014; Usiskin, 1982) there are five levels of geometric thinking, namely 1) Level 0 or visualization level where students recognize geometric forms only as visual characteristics of an object; 2) level 1 or the analysis level where student analyze the concepts and properties of geometric shapes; 3) Level 2 or the informal deduction level where students can see the relationship between the properties of a geometric shape and the properties of various shapes by using informal deduction as well as classify the shapes hierarchically; 4) Level 3 or formal deduction where students receive and compile evidence; and 5) Level 4 or rigor level where students reason formally in mathematical systems and can analyze the consequences of manipulating axioms and definitions. Based on the description, students' geometric understanding starts from visual observation to spatial understanding. Roskawati et al. state that geometry combines the presentation of abstractions from visual and spatial experiences, for example, fields, patterns, measurements, and mapping (Roskawati et al., 2015).

Measurement is the process, method, and act of measuring by calculating the size (length, size, area, and height) with specific tools (Great Indonesian Language Dictionary). In other words, measurement is a process of comparing an object's attributes with the same attributes of a measuring instrument (Van De Walle and Folk, 2005; Wijaya, 2009). Suppose that length is an attribute of an object which can be determined by measuring how far it is between two ends of the object. The measurements mentioned in the Quran include measurements of length (distance), time, area, weight, and velocity. Quran also describes the operations that involve a unit of measurement. One of the verses related to measurement is surah Al-Furqon (25): 2, ... and has created each thing and determined it with (precise) determination.

The verse above implies that the word "measure" exists in nature, which can be expressed in two roles, the first as a number with nature and accuracy in it and the second as a law or rule (Romlah, 2011), A measurement contains the properties of an object. Measurement learning materials include length, time, weight, distance, velocity, unit of quantity, area, and volume of objects. Students determine the circumference and area of a plane at the elementary school level and determine the surface area and volume of shapes. Students relate the formula for the circumference and area of various types of rectangles at the junior high school level, distinguish and determine the surface area and volume of plane shapes, and generalize the surface area and volume of various curved side spaces.

Previous research conducted by Nihayati et al. investigates the verses related to numbers and concludes that the integration of mathematics with Islamic values can be found in surah AsSajdah verse 5 number 1, surah Al-Maidah verse 73 number 3, surah Al-Baqarah verse 261 numbers 7 and 100, surah Al-Anfal verse 65 numbers 20, 100, 200, and 1,000, and surah AlAn'am verse 160 numbers 10 (Nihayati, Suningsih \& Abdullah, 2018). Mahdalena studies the concept of numbers, shapes, and connections in the Quran (Mahdalena, 2018). Furthermore, research conducted by Abdusakir reveals that the internalization of religious values in mathematics learning can be carried out through infusion, analogy, narrative, and immersion 
strategies (Abdussakir, 2018). The integration of mathematics with the Quran on geometry and measurement materials has not been widely used. Based on this description, this study's purpose was to examine the verses of the Quran, which contain the concept of geometry and measurement so that it can develop human potential intellectually and spiritually.

\section{The Research Methods}

This research employed the descriptive-qualitative method with library research design. The steps in this research were searching for and detecting verses of the Quran related to geometry and measurement material and classifying the verses containing the concept of geometry and measurement. The analysis process refers to the interpretation of Al-Jalalayn and the interpretation of Ibn Kathir.

\section{The Results of the Research and the Discussion}

\section{a. Geometry in the Quran}

The geometric concepts contained in the Quran, according to this research, are lines and angles. The word "line" can be found three times, and the word "angle" can be found twice. The details of the concept of geometry in the Quran are presented in Table 1.

\section{Table 1. Geometry Concepts in the Quran}

\begin{tabular}{cclc} 
No. & Geometry Concepts & \multicolumn{1}{c}{ Surah and Verses } & Occurrence \\
\hline 1. & Line & Surah Al-'Anbiya (21) verse & \\
& & 33 & Three times \\
2. & Line & Surah Yasin (36) verse 40 & \\
3. & Line & Surah Fatir (35) paragraph 27 & \\
4. & Angle of & Surah Al-Fatihah (1) verse 6 & Two times \\
5. & Angle of & Surah Ar-Ra'd (13) verse 2 & \\
\hline
\end{tabular}

A geometric plane is a set of points connected continuously (straight or curved), which has only one endpoint and one starting point. Lines are not only straight, but there are also curved lines, as displayed in Figure 1.
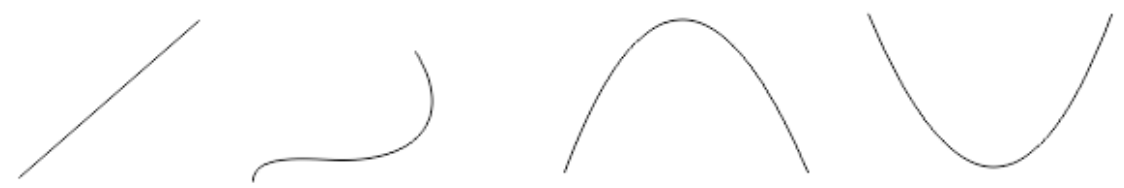

Figure 1. Examples of Lines

The geometric concept of lines is found in surah Al-'Anbiya (21) verse 33, which means "And $\mathrm{He}$ is the One Who created the day and the night, the sun and the moon-each travelling in an orbit." It also can be found in the surah, namely surah Yasin (36) verse 40, which means $"$ is not for the sun to catch up with the moon, ${ }^{1}$ nor does the night outrun the day. Each is travelling in an orbit of their own". Based on these two verses, science reveals that the moon rotates on its axis and revolves around the earth. Earth and moon also revolve around the sun. Likewise, the stars, sun, and moon circulate in their respective orbits orderly and neatly so that no collisions occur. Scientists have found that the moon travels in a curved line. It moves circular, not in a straight line (Thayyarah, 2013). The concept of the line is that each celestial body has its axis and path called an orbit. Likewise, the earth's rotates on its axis makes day and night come and go. 
Surah Fatir (35) verse 27 reads, do you not see that Allah sends down rain from the sky with which We bring forth fruits of different colors? Moreover, in the mountains are streaks of varying shades of white, red, and raven black. Allah sends rain from the sky and then grows fruits of various kinds; some are green, red, yellow, and other colors and various tastes and smells. The verse "And in the mountains are streaks" contains the Arabic word judadun, the plural form of juddatun, meaning mountain roads. The part of the verse that says "white, red and yellow (which have various colors) some are old and some are young and some are pitch black" is converted to the pronunciation "judadun," which means large dark stones (Tafsir Jalalayn).

An angle is an area composed of 2 straight lines that intersect at a point that forms the vertex and the angle's leg. The angles can be seen in Figure 2.

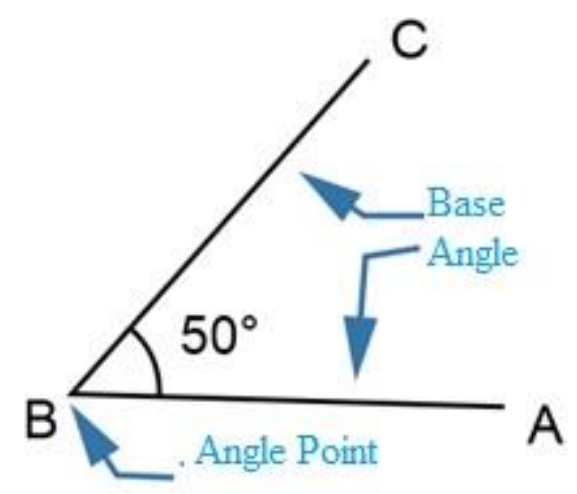

Figure 2. Geometric Plane's Angles

Based on the size (x), angles are classified into five types (Schmidt, 2005), namely:

1. A zero degree angle is an angle with $x=.0^{\circ}$

2. An acute angle is an angle with $00<x<90 o$

3. A right angle is an angle with $x=900$

4. An obtuse angle is an angle of $900<x<1800$

5. A straight angle is an angle with $x=180$ o

6. A reflex angle is an angle with $180 \mathrm{o}<\mathrm{x}<360 \mathrm{o}$

7. A full angle is an angle with $\mathrm{x}=360^{\circ}$.

The concept of angles in the Quran presents in several verses. First, surah Al-Fatihah (1) verse 6 , which means show us the straight path. The verse shows that humans ask Allah to guide them to the right path by following Allah's orders and His Messenger. Whoever follows the right path means that he is following Islam's path, which is the only religion that is blessed by Allah. Whoever follows the path of Islam follows the Quran, which is the book of Allah/the rope of Allah/the straight path. Associated with the concept of geometry, a straight road means to form a $180^{\circ}$ angle.

Second, surah AR-Ra'd (13) verse 2, which means it is Allah Who has raised the heavens without pillars - as you can see - then established Himself on the Throne. He has subjected the sun and the moon, each orbiting for an appointed term. He conducts the whole affair. He makes the signs clear so that you may be sure of the meeting with your Lord. Based on the verse, Allah tells about His power's perfection by only with His permission and command; the sky is lifted without supporting pillars. The second part of the verse says, then He reigns over the Throne in the sense of the power worthy of His majesty and subdues the sun and the moon. The expression taraunaha (you see) implies that Allah has lifted the heavens with a pillar that you cannot see. 
These pillars are the gravitational force that regulates the order of the entire universe from atoms to galaxies. For example, the sun is pulling the earth with such a tremendous gravitational force that the earth is evolving towards the sun in a circular orbit and forming an angle of $360^{\circ}$ (full angle). Sun and moon are circulating in its orbit until the specified time, which is the resurrection day.

\section{b. Measurement in the Quran}

The concepts of measurement found in the Quran are time, weight, area, and distance. There are six concepts of time, four concepts of weight, two concepts of area, and two distance concepts. The details of the concept of measurement in the Quran are presented in Table 2.

Table 2. The Concepts of Measurement in the Quran

\begin{tabular}{|c|c|c|c|}
\hline No. & Concepts & Surah and Verses & Occurrence \\
\hline 1. & Time & Surah Al-Baqarah (2) verse 228 & \\
\hline 2. & Time & Surah At-Taubah (9) verse 36 & \\
\hline 3. & Time & Surah Yunus (10) verse 14 & \\
\hline 4. & Time & Surah Ar-Rahman (55) verse 5 & Six times \\
\hline 5. & Time & Surah Al-An'am (6) verse 96 & \\
\hline 6. & Time & Surah Al-Qadr (97) verse 3 & \\
\hline 7. & Weight & Surah An-Nisa '(4) verse 40 & \\
\hline 8. & Weight & Surah Luqman (31) verse 16 & Four times \\
\hline 9. & Weight & $\begin{array}{l}\text { Surah Az-Zalzalah (99) verses } 7 \\
\text { and } 8\end{array}$ & \\
\hline 10. & Area & Surah Noah (20) verse 20 & \\
\hline 11. & Area & Surah Al-AnKabut (29) verse 56 & Two times \\
\hline 12. & Distance/Length & Surah An-Najm (53) verse 9 & \\
\hline 13. & Distance/Length & Surah Saba' (34) verse 18 & Two times \\
\hline
\end{tabular}

Time is the interval between two states or events and the duration of an event (Murniyetti, 2016). The unit of time in mathematics are hours, days, minutes, months, and many others. Several verses of the Quran related to the concept of time are described as follows.

Surah Al-Baqarah (2) verse 228, which means divorced women must wait for three monthly cycles 'before they can re-marry'. It is not lawful for them to conceal what Allah has created in their wombs, one if they 'truly' believe in Allah and the Last Day. Moreover, their husbands reserve the right to take them back within that period if they desire reconciliation. Women have rights similar to those of men equitably, although men have a degree 'of responsibility' above them. And Allah is Almighty, All-Wise.

Based on that verse, Allah orders divorced women who have been committing sexual acts to have a quru' period. Let them wait for three quru' periods as their iddah period; then, they can marry if they wish. Based on the medical theory, iddah is intended to cleanse a woman's uterus after divorcing her husband. Also, it allows reconciling during the iddah period. There are two opinions regarding the measurement of time, namely the quru' unit which means holy or menstruation. The three quru' periods contain sacred intention, which is to provide convenience to women and give postponement time for husbands. Meanwhile, the three quru' periods as menstruation means further extending the postponement period for the husband because divorce cannot be executed while the woman is in an unclean state (Istikomah \& Zubir, 2019). The quru' unit of time cannot be stated by months or days because the menstrual cycle for each woman can vary $(28,29,30$ days, and so on). 
Surah At-Taubah (9) verse 36, which means indeed, the number of months ordained by Allah is twelve - in Allah's Record ${ }^{1}$ since the day He created the heavens and the earth - of which four are sacred. That is the Right Way. So do not wrong one another during these months. And together fight the polytheists as they fight against you together. And know that Allah is with those mindful of Him. The verse confirms that there are 12 months in the Islamic calendar, namely Muharram, Shafar, Rabi'ul Awal, Rabi'ul Akhir, Jumadil Awal, Jumadil Akhir, Rajab, Sya'ban, Ramadhan, Syawal, Dzulqa'dah, and Dzulhijjah. The four haram (holy) months are Muharram, Rajab, Dzulqa'dah, and Dzulhijjah. Don't you persecute (yourself) in those four months by committing disobedience? The four months are haram (holy) months whose holiness is exalted. The sanctions for sinful acts committed during these months are magnified, and the merits of righteous deeds are also enlarged. Thus, the unit of measurement used here is the unit of the month.

Surah Yunus (10) verse 5, which means He is the One Who made the sun a radiant source and the moon a reflected light, with precisely ordained phases, so that you may know the number of years and calculation of time. Allah did not create all this except for a purpose. He makes the signs clear for people of knowledge. Next, surah Ar-Rahman (55) verse 5, which means the sun and moon (circulate) according to calculations." These verses show that Allah has made the sun and the moon as the standard in calculating the time of day, month, and year as guidance for humans. This verse is in line with the field of astronomy where the moon's rotation on its axis and the moon's revolution towards the earth is a time marker for humans, namely one month (Qamariyah). Likewise, the earth's revolution around the sun marks one year's time calculation (Syamsiyah). One Syamsiyah year has 365 days, or to be precise, 365.1422 days. One Qamariyah year is 354 days, or to be precise, 354,36760 days. This is a sign of divine power.

Surah Al-An'am (6) verse 96, which means He raises the morning, makes the night to rest, and (makes) the sun and moon for reckoning. That is the provision of Allah the Almighty, the All-Knowing. This verse explains the functions of night and day. Allah made the day a time to earn a living and prosper the earth and made the night a time to rest, sleep, and relax from fatigue after a day's work. Besides, the change of day and night is significant for the measurement of time calculation.

Surah Al-Qadr (97) verse 2-3, which means, and do you know what the night of glory is? The night of glory is better than a thousand months. Mathematically, the measurement of time uses the night unit and the month unit. The verse explains that Allah glorifies the position of Lailatul Qadar by doing good deeds. The reward is much more significant and better than a thousand months.

Weight is the amount of pressure/weight (Great Indonesian Language Dictionary). The units of weight in mathematics are grams, kilograms, quintals, tons, and so on. Several Quranic verses related to weight are described as follows.

Surah An-Nisa' (4) verse 40, which means indeed, Allah never wrongs 'anyone —even by an atom's weight. ${ }^{1}$ And if it is a good deed, He will multiply it many times over and give a great reward out of His grace. Surah Luqman (31) verse 16 which means Luqmân added, ' "O my dear son! 'Even' if a deed were the weight of a mustard seed - be it 'hidden' in a rock or in the heavens or the earth-Allah will bring it forth. Surely Allah is Most Subtle, All-Aware". In another verse, surah Az-Zalzalah (99) verses 7 and 8, which means whoever does well as much as dzarrah, surely he will see (retribution). Furthermore, whoever does evil as big as dzarrah, surely he will see (reply) it too. The concept of weight measurement discussed in these verses is the unit of 
dzarrah. Good or evil as heavy as dzarrah will get a reward from Allah SWT. Dzarrah means the smallest ant, which is as heavy as a small ant (Tafsir Ibn Kathir). In a narration, it is stated that when surah Al-Insaan verse 8 was revealed, the Muslims considered that people who gave a little charity would not get a reward and also people who commit minor sins such as lying, cursing, peeping, and so on are not punished. They thought that the threat of hellfire is reserved for people who are gross sinners. So, these verses were revealed as a rebuttal to their assumptions. Also, these verses motivate the spirit of Muslims to do good deeds even a little because a small good deed will eventually become a lot. At the same time, Allah warns them to avoid evil deeds even though they are small because small evil deeds will eventually become big.

The area is a measure of a field's length and width (field, room, and others) (Great Indonesian Language Dictionary). The units of the area in mathematics are square meters $\left(\mathrm{m}^{2}\right)$, square decimeters $\left(\mathrm{dm}^{2}\right)$, square centimeters $\left(\mathrm{cm}^{2}\right)$, hectares (ha), acre (a), centiacre (ca), and so on. Several verses of the Quran related to the area are described as follows.

Surah Noah (20) verse 20, which means to walk along its spacious pathways. The concept of measurement in this verse is the unit of area, and the implied meaning is that Allah has created the earth widely for human settlement to travel wherever they want. Tafsir Ibn Kathir explains that these are among what Prophet Noah reminded his people, to show them the power of Allah and His greatness through His creation of the heavens, the earth, and all the blessings they enjoy in the form of earthly and heavenly benefits. He is Allah, who creates and gives sustenance. He has made the heavens a roof and the earth as a stretch and bestows His sustenance upon His creation. Then He is God who must be worshiped and celebrated and may not be associated with anything.

Surah Al-AnKabut ( 29) verse 56, which means O My believing servants! My earth is genuinely spacious, so worship Me 'alone'. The concept of measurement in this verse is the unit area. This verse's implied meaning is that Allah commands His servants to migrate from a country where they cannot uphold their religion because Allah's earth is vast.

Length or distance is the longitudinal distance from end to end. The units of length in mathematics are meters $(\mathrm{m})$, decimeters $(\mathrm{dm})$, centimeters $(\mathrm{cm})$, inches, feet, and so on. Several verses of the Quran related to length or distance are described as follows.

Surah An-Najm (53) verse 9, which means that he was only two arms-lengths away or even less. The measurement concept of this verse is the length or distance of two arrowheads. This incident occurred during Isra when Jibril directly approached Prophet Muhammad when he came down to meet him on earth. The distance between the Jibril and Prophet Muhammad was the same as two stretched arrowheads. In Tafsir Ibn Kathir, two cubits are the same as the two ends of an arrow, as narrated by Ibn Jarir and Ibn Abu Hatim through Ibn Wahb's hadith. Although mathematically, it is not explained how long the bow is, it is interpreted in cubits ( 1 cubit $=45$ centimeters).

Surah Saba' (34) verse 18, which means we had also placed between them and the cities We showered with blessings 'many small' towns within sight of one another. Moreover, We set moderate travel distances in between "saying," "Travel between them by day and night safely." This verse explains "placed between them" as the inhabitants of Saba's land in Yemen. The word "the cities We showered with blessings" with the abundance of water and the abundance of trees means the villages of the land of Sham. The land of Syria was a trading destination (many small towns within sight of one another) from Yemen to Sham (and We determine between these countries travel distances) to rest in one place and then stay at another place until the end of their 
journey. On their way, they no longer need to carry supplies and water. We say (Travel between them by day and night safely) without feeling any more fear. Mathematically, between Yemen and Syria (Jordan, Syria, Lebanon, and Palestine) can be reached with a certain distance, which requires a specific travel time.

\section{Conclusion and Suggestion}

The Quran contains five concepts of geometry, namely three concepts of lines and two concepts of angle. Meanwhile, there are fourteen concepts of measurement: six concepts of the time unit, four concepts of weight, two concepts of area, and two concepts of length or distance.

\section{References}

Abdussakir, A. (2018). Keynote Speech presented in The 1st International Conference on Mathematics and Islam (ICMIs). 67.

Chiu, M.-S. (2007). Mathematics as Mother/Basis of Science In Affect: Analysis of TIMSS 2003 Data. Proceedings of the 31 Conference of the International Group for the Psychology of Mathematics Education, 2, 145-152.

Clements, D. ., \& Batttista. (1992). Geometry and Spatial Reasioning. in D.A. Grows, (ed.) Handbook of Research on Teaching and Learning Matematics.

Crowley, M. L. (1987). The Van Hiele Model of the development of geometric thought. Learning and Teaching Geometry, K-12, 1-16. http://www.csmate.colostate.edu/docs/math/mathactivities/june2007/The van Hiele Model of the Development of Geometric Thought.pdf

Harahap, E., Sukarsih, I., Gunawan, G., Yusuf Fajar, M., \& Darmawan, D. (2016). A ModelBased Simulator for Content Delivery Network using SimEvents MATLAB-Simulink. Insist, 1(1), 30-33. https://doi.org/10.23960/ins.v1i1.13

Istikomah, A., \& Zubir, M. (2019). Analisis Iddah Berdasarkan Pemanfaatan Teknologi Kedokteran dalam Menafsirkan Tsalatsatu Quru'. 1(1), 31-45. http://ecampus.iainbatusangkar.ac.id/ojs/index.php/istinarah/index

Mahdalena. (2018). Kajian Konsep Bilangan, bentuk, dan Koneksi dalam Al-Quran. Itqan, 9(2), $1-15$.

Mas'ud, M. (2008). Subhanallah..., Quantum bilangan-bilangan Al-Qur'an. Diva Press.

Murniyetti. (2016). Waktu Dalam Perspektif Al-Qur'an. 93-101.

Nasution, A. F. (2017). Jurnal EduTech Vol. 3 No. 1 Maret 2017. 3(1), 1-11. https://doi.org/jmn0228-3 [pii]

Nata, A. (2018). Islam Dan Ilmu Pengetahuan. Prenadamedia Group.

Nihayati, Suningsih, A., \& Abdullah, H. M. (2018). Integrasi Ayat-Ayat Bilangan Dalam AlQur' an Dengan Nilai-Nilai Islam. UIN Raden Intan Lampung, 03(02), 101-109.

Nurani, I. F., Irawan, E. B., \& Sa'dijah, C. (2016). Level Berpikir Geometri Van Hiele Berdasarkan Gender pada Siswa Kelas VII SMP Islam Hasanuddin Dau Malang. Jurnal Pendidikan, 1(5), 978-983.

Priyanto, A. R. (2009). Segi Enam Pada Sarang Lebah Madu Dalam Sains Dan Islam. UIN 
Sunan Kalijaga Yogyakarta.

Raharjo, M. D. (2002). Ensiklopedi Alquran: Tafsir Sosial Berdasarkan Konsep-Konsep Kunci. Paramadina.

Romlah. (2011). Ayat-Ayat Al-Qur'an dan Fisika. Harakindo Publishing.

Roskawati, Ikhsan, M., \& Juandi, D. (2015). Analisis Penguasaan Siswa Sekolah Menengah Atas pada Materi Geometri. Didaktik Matematika, 2(1), 64-70.

Rouadi, N., \& Husni, N. (2014). Demonstration in Euclidean Geometry. 3(1), 130-138. http://www.aijssnet.com/journal/index/155

Safrina, K., Ikhsan, M., \& Ahmad, A. (2014). Peningkatan Kemampuan Pemecahan Masalah Geometri melalui Pembelajaran Kooperatif Berbasis Teori Van Hiele. Jurnal Didaktik Matematika, 1(1), 9-20. https://doi.org/10.24815/jdm.v1i1.1238

Schmidt, P. A. (2005). Geometri. Erlangga.

Suprayogo, I. (2016). Membangun Integrasi Ilmu dan Agama: Pengalaman UIN Maulana Malik Ibrahim Malang. Batusangkar International Conference, 1(October), 27-46.

Thayyarah, N. (2013). Buku Pintar Sains dalam Al-Quran: Mengerti Mukjizat Ilmiah Firman Allah. Zaman.

Usiskin, Z. (1982). Van Hiele Levels and Achievement in Secondary School Geometri.

Van de Walle, J. \& Folk, S. (2005). Elementary and Middle School Mathematics. Teaching Developmentally. Toronto: pearson Education Canada Inc

Wijaya, A. (2009). Hypothetical Learning Trajectory dan Peningkatan Pemahaman Konsep Pengukuran Panjang. Prosiding Seminar Nasional Matematika dan Pendidikan Matematika Jurusan Pendidikan Matematika FMIPA UNY 5 Desember 2009. hal 373-387. 